\title{
1: 147365209-147360110
}

National Cancer Institute

\section{Source}

National Cancer Institute. 1:147365209-147360110. NCI Thesaurus. Code C44961.

Physical location of MCL1_Gene 